DANDELION

postgraduate arts journal \& research network

VOLUME 5 NUMBER 2 SPRING 2015
TOM HENDRY'S research and academic background spans the study of history, literature and film studies. After gaining a degree in history at Queens' College, Cambridge, he had a long career in Information Technology. Tom later did a Masters course with the Open University combining the study of modern English Literature and film studies. His final-year dissertation was a comparative study of the intertextuality of films and literature with reference to the filmic adaptations by Ken Russell of D.H. Lawrence's major novels. Tom is now a second year MPhil/PhD candidate with FMACS, Birkbeck College, London studying adaptation and the novels of Cormac McCarthy.

\title{
Myth, Legend and Dust: \\ Cormac McCarthy and the loss of the vernacular
}

\author{
Tom Hendry
}

In this paper, I Will EXAmine Cormac McCARthy's latest novel The Road (2006) and the 2009 film adaptation for their depiction of the loss of the everyday and the threat of mass extinction. ${ }^{1}$ Although we are all faced with loss throughout our lives, we are generally able to find a way of coping with personal tragedy and trauma. Natural resilience and optimism helps us move on. In many ways, this emotional and material recovery is made possible by the retention of hope and the belief that things will get better.

However, the outlook that McCarthy constructs in his novel is a postapocalyptic nightmare of death, and decay into nothingness. The novel and the film both depict the aftermath of an undefined disaster; this turns the surviving humans into feral animals reduced to violence and cannibalism to survive. This paper considers critical and scholarly response to the works to help us decide whether the final destination of the road is a metaphor for despair or hope.

Cormac McCarthy was born in 1933 in Rhode Island. However, at the age of four his parents and family moved south to Knoxville, Tennessee. McCarthy is today, at the age of eighty, one of the most famous and accomplished of American writers now considered in the tradition of Twain, Melville and Faulkner. McCarthy has also become recognised for his stage plays, and for adapted and original screenplays. However, widespread fame and recognition did not come quickly for McCarthy. In 1965, when his first novel The Orchard Keeper was published, McCarthy was little known outside of a small group of local Southern writers and subsisted on a number of literary 
scholarships. His first five novels struggled to sell more than 5,000 copies and it was not until All the Pretty Horses in 1992 that he broke through to the mass market.

Cormac McCarthy's early novels were set in Tennessee, whilst his later move to El Paso resulted in the extension of his interest in Texas and the Mexican borderlands for his later works. For McCarthy, these lands largely symbolised the decline of the mythology of American ideals of frontier and of the civilising of the wilderness, with his lyrical descriptions of the landscape and nature counterpointing the decay of the rural past and the ever-present evil in his stories: 'Evil hovers over the corpus of McCarthy's writings, like a vulture, waiting to descend. ${ }^{2}$ McCarthy's later novels also show his exploration of the inter-cultural issues and ethnicity of the Southwest, together with the decline of the myths of American pastoral utopianism.

From his earliest work, The Orchard Keeper, Cormac McCarthy celebrates the everyday, especially in the poor and dispossessed people of Tennessee. He seeks to deconstruct and question the myths of the American pastoral wilderness and the manifest destiny of the West. In doing this, McCarthy suggests that the language of the American settlers' God-given role of civilising lesser races, the fact that the settlers saw themselves as the champions of the free world and the creation and protection of an American Eden are all devalued by experience. McCarthy sees these early ideals of the New World as lost forever. Indeed, the last paragraph of The Orchard Keeper, in which a key character spends his life tending a wasted, non-productive orchard seems to set the scene - and the philosophical and existential tone - for all of McCarthy's future works. ${ }^{3}$

They are gone now. Fled, banished in death or exile, lost, undone. Over the land sun and wind still move to burn and sway the trees, the grasses. No avatar, no scion, no vestige of that people remains. On the lips of the strange race that now dwells there their names are myth, legend, dust. ${ }^{4}$

\section{Introduction: From Text to Film - Research Sources}

In order to achieve a balance between the literary appreciation of the original text of The Road, and the appreciation of the John Hillcoat's film adaptation, I chose to research works by both literary scholars (such as John Cant and Stephen Frye) and media scholars (including Mark Foster and Jim Welsh). Since Cormac McCarthy is somewhat of a recluse and prefers the company of scientists to that of literary scholars, I also included the content of the only three public interviews that McCarthy has ever given - namely two with Richard Woodward of the New York Times and a famous interview with Oprah Winfrey on CBS in 2007. I do also cite a number of articles on religious, philosophical and metaphysical readings of the film and text of The Road (including Hanna Boguta-Marchez, Thomas A Carlson and Lydia Cooper) since they offer some original and interesting interpretations of McCarthy's works.

\section{The Novel}


The Road appears to be a significant departure for McCarthy involving the desperate quest of an unnamed father and son to survive an unexplained, and seemingly global, disaster. In The Road, the erasure of history and civilisation is placed in the near future, whereas all of McCarthy's earlier works are placed in the past. I will try to show that the novel is, in fact, a continuation of McCarthy's preoccupation with the essence of evil and the decline of American utopianism and a powerful allegory that seems to predict the final breakdown of society and the onset of cultural entropy.

John Cant, in perhaps the most complete scholarly book on McCarthy's works, ${ }^{5}$ agrees that in The Road 'we are present in another of McCarthy's allegorical worlds'. ${ }^{6}$

He suggests that The Road can be seen to depict modern America (and by implication the whole of the Western world) as literally and metaphorically a waste land, with a rural past as corrupt and devalued; he further argues that there is a continuity throughout McCarthy's works that depicts the failure of the 'grand narrative' of American Exceptionalism.

The onset of cultural entropy, I would argue, is present in all of McCarthy's works and is frequently associated with the breakdown of the great 'American Myths' of 'frontier', 'certainty' and the 'divine destiny'- what John Cant calls 'American Exceptionalism'. At an everyday level this includes the right to own and farm land, the right to use a gun to protect your homestead and the sanctity of the 'nuclear family'. For many decades this model was celebrated in so called classic Westerns, and became ingrained in the mythology of Hollywood. In both the book and the film, the father fails to inspire the son with a visit to his albeit ruined, childhood home and has difficulty in explaining to the young boy what 'neighbourhood' means. The referents that the father takes for granted no longer have meaning.

Lydia Cooper suggests a different interpretation of The Road -as a quest to find the lost holy grail of Jesus perhaps echoing the early Arthurian legends. She echoes others who see the novel as a response to an 'immediate and visceral fear of cataclysmic doom after in the US 9/11'.7 Cooper questions whether human beings deserve to survive or whether the decline of the West and America has gone 'beyond redemption'.

She suggests that the constant reference to 'carrying the fire' in the novel is a metaphor for the practice of civility and ethics now so endangered.

The Road depicts a nightmare world of fire and ash as a visual metaphor for death and cultural entropy. Cooper also describes The Road as 'a viscerally realistic wasteland ${ }^{8}$ and also sees the devastation as a metaphor for internal corruption.

\section{The Film}

Jim Welsh thought that John Hillcoat made an admirable attempt to film the 'unfilmable [...] because it takes an unwatchable film to perfectly adapt an unreadable novel, and, besides, disturbing the audience is not exactly the way to sell tickets'. ${ }^{9}$ Critic Janet Maslin's review of the film was entitled 'The Road through Hell, Paved with Desperation'. ${ }^{10}$

The film starts (before the credits) with a vividly coloured sequence of summer bliss with bright sunshine, beautifully blooming flowers, and a happy couple with the wife pregnant. These initial images are accompanied by beautiful lyrical music. As they go indoors, a grey shutter closes on the scene and reduces the world to dull, sepia colours. The closing of the grey shutter, I suggest, becomes a metaphor for the world that is lost and the switch to largely 
monochrome photography, which describes the fading of civilisation. McCarthy writes at the start of the novel of: 'Nights dark beyond darkness and the days more gray each one than what had gone before. Like the onset of some cold glaucoma dimming away the world. ${ }^{11}$

The couple are awakened during the hot, sultry night by explosions and cries of distress outside. The man goes to fill the bath to provide critical water for what seems to have been an anticipated disaster, the nature of which is never made clear. The film then cuts to a dark, black, cold scene in ash-covered woods comprising only dead trees where the father and son huddle in the night. The music has also changed to become harsh and threatening.

This first, intensely coloured sequence of the film does not appear until after fifty pages of the novel, and then only as one of the father's many dreams. The filmmakers clearly decided to use this device to foreground an explanation of why the father and son are fighting for survival in a post-apocalyptic world. We are thrown quickly into a world of 'myth, legend and dust' where hope and expectation will die with memory.

The world shrinking down about a raw core of parsible entities. The names of things slowly following those things into oblivion. Colors. The names of birds. Things to eat. Finally the names of things one believed to be true. More fragile than he would have thought. How much was gone already? The sacred idiom shorn of its referents and so of its reality. Drawing down like something trying to preserve heat. In time to wink out forever. ${ }^{12}$

One of the very early images of the film shows the father pushing a super-market trolley with their scant belongings and remaining food and water. This is at once a powerful metaphor of homelessness, wandering and hunger. This imagery is sustained for most of the film until, eventually even this breaks down when the man no longer has the strength to push it.

The son, born after the initial disaster, is partly feral who is unfamiliar with the basic trappings of human society - shopping, sitting at a table, and even just walking up stairs.

Flashbacks are frequently used in the film to fill in the back-story. We learn of the wife/mother's rejection of survival. She hopes only for death as an 'eternal nothingness and I hope for it with all my heart.' ${ }^{13}$ She commits suicide preferring death as a 'lover' rather than facing a long, hopeless struggle for survival. In a strongly filmic reference, McCarthy has the mother protest that there would be no 'survival' and that they were 'the walking dead in a horror movie'. ${ }^{14}$ Interestingly, the filmmakers chose not to use this line in the film. I suggest that, although McCarthy wanted to make a reference outside of the apocalyptic genre, the filmmakers preferred to maintain the overall suspension of disbelief.

The film picks up McCarthy's constant theme of 'man's insignificance in a godless world' with the father and son ${ }^{15}$ as 'two hunted animals', 'cast adrift in a world in which civilisation and its concomitants have been destroyed. ${ }^{, 16}$

\section{Towards Total Entropy and Inertia}

Mark Foster, in his article 'The Lonely Road', ${ }^{17}$ wrote of 'a sudden and total destruction of the taken-for-granted network of cause and effect upon which all narratives (about life, society, the world) had, up until then relied.' Foster sees the Earth as a 'burnt-out husk that approaches this final stage of material death tending towards total entropy and inertia'. 
In this section, I will pick up and develop Foster's concept of 'total entropy' and deal with it across three main ontological themes:

- Material, Economic and Informational Entropy

- Cultural Entropy

- Psychological and Spiritual Entropy

\section{Material, Economic and Informational Entropy.}

This involves the loss of the vernacular, and the referents of every day 'things' that keep us fed, healthy and motivated. Many of the references to these 'lost things' are vividly described in the text of the novel in in a strongly pictorial way, which lends itself to being transposed into filmic images. Thus we can readily associate the loss of televisions, radios and newspapers with a total loss of information. It takes more imagination to empathise with the total lack of use of telephone directories and maps. In the film, the father's map slowly disintegrates until it is useless, although the referents for direction and whereabouts have long since vanished. They may indeed still engender some memories, but even these and their utility dwindles by the day. The inclusion of shots of old advertising hoardings with their now useless information, supermarkets and petrol stations with only empty tanks, freezers and fridges serve to intensify the pain of loss and the challenge to even survive. Crop fields are now only dust bowls of ash offering no promise of future food, only increasing the desperation to survive. The lyrical landscape so redolent of all of McCarthy's works is now only seen in flashbacks and in the new reality is reduced to dust and ashes. Money is now worthless and piles of Kruggerrands readily discarded. The certainties and security afforded by material wealth is now obsolete.

Thomas A Carlson also notes that previously 'referent things' like newspapers, billboards, money, credit cards, driver's licenses, ATMs, markets and stores, telephones, books, cars, trains and 'their now pointless, empty routes', had all been lost in what Carlson calls 'the eclipse or closure of worldly memory and expectation ${ }^{, 18}$. The few survivors were 'radically deprived of the things and persons in relation which and with whom one normally exists, those who travel the road find themselves and their existence thrown into absolute question. ${ }^{19}$ In a poignant and powerful sequence in both the book and the film, the father discards first his credit card, then his picture of his dead wife and then his wedding ring, thus totally expunging the last 'things' he had to link himself with the life that has gone.

There is nothing to break the monotony of daily survival of father and son. The threats - mainly of being raped, killed and eaten - are ever present but the biggest challenge is finding food and safe water.

The story has little plot. It is merely a long, painful road to survival whatever that might actually mean. Words are sparse and only flashbacks in McCarthy's lyrical style offer any relief. Indeed, in the film, these flashbacks, which are mostly the man's dreams, are all in colour and serve to increase the intensity of their ordeal. The father suggests to the boy that the more colourful your dreams the closer you are to death and this is borne out just before he dies with intense images of previous happiness with his wife.

The Road is a lament for the loss of conventions and objects that we take for granted in our present life that represents the comfort and security of civilisation as exemplified by the American 'myth'. The book expresses a profound tenderness for the artificial, for human-made objects. Thus we see in a dream/flashback of the father fishing at his uncle's farm, detailed description 
of fishing tackle, shoes, hats, a cob pipe and manila rope ('A radio somewhere') together with an evocation of the environment and its natural splendour. ${ }^{20}$ The scene is coloured with the nostalgia of the simple life before the apocalypse, with McCarthy continuing to evoke the loss of everyday things and the severing of happy memories. This scene is not used in the film.

A scene from the book that is faithfully recreated in the film is when the father finds and almost ritualistically opens a single can of Coca Cola from a destroyed dispensing machine. Here we have a scene that gives the can a totemic quality far beyond its singularity. It both invokes a world lost and the safety and confidence of the world evinced, but also the overtones of Coca-Cola as a symbol of rampant and destructive capitalism in the world now under dire threat of extinction.

This incident with the Coca-Cola can and an earlier sighting of a 'See Rock City' advertisement in the blackened ashes of a past world, expresses a lament triggered by fading 'things' of the past that would not have been given a second thought before but have now maybe gone for ever. The posters have faded, and even the palimpsests of the past have gone.

McCarthy frequently observes the traces of previous consumer objects - 'advertisements for goods which no longer exist'. Hillcoat and his creative team frequently include shots of 'things that no longer exist'. I think that the visual imagery of the film translates very well the descriptive achievement of the original novel.

\section{Cultural Entropy.}

The theme of the lack of trust in the future is frequently foregrounded in The Road. As the father and son journey south towards the sea, which seems to bring with it some spurious hope for salvation, the journey seems increasingly more desperate and pointless. Another time they find a huge but ruined house. Once splendid with fine fixtures (including a grand piano) but now turning to dust with a library where the father, surrounded by pools of fetid water, picked up one of the books and thumbed through the heavily bloated pages:

He'd not have thought the value of the smallest thing predicated on a world to come. It surprised him. That the space which these things occupied was itself an expectation. He let the book fall and took a last look around and made his way out into the cold gray light ${ }^{21}$

To the dying man, books were not so different from the ancient artefacts that he finds on their desperate journey, such an antique bucksaw, an old Spanish coin, an Indian arrowhead and, perhaps most poignantly of all (but not referenced in the film) a brand new, but useless sextant. All these things signal the erasure of the past and the empty expectations of the future.

The Road is indeed a nightmare world of fire and ash as a visual metaphor for death and cultural entropy with descriptions of The Road as 'a viscerally realistic wasteland' ${ }^{22}$ with the devastation as a metaphor for internal corruption. 


\section{Psychological and Spiritual Entropy (Loss of hope and faith?)}

This category of entropy suggested by McCarthy is perhaps the most problematic, in that it relies upon a largely suggested, but not confirmed, religious interpretation of the story. Lynda Cooper argues strongly for an interpretation of The Road as a 'Quest for the lost Holy Grail of Jesus' and ultimate redemption. There is, indeed, a piece of evidence that would seem to confirm authorial intention with the existence of a McCarthy draft of the novel actually entitled 'The Grail'. ${ }^{23}$ Cooper also echoes the decline of the American 'dream' and questions whether human beings deserve to survive or whether the decline of the West and America has gone 'beyond redemption'.

There is a constant reference to 'carrying the fire' in the novel and film which appears to be a metaphor for the practice of civility and ethics now so endangered, whilst Hanna Boguta-Marchez goes further and sees it as a representation of the 'meaning of life' with the fire as a symbol of the human soul and a way to connect to God. The son constantly questions as to whether only the 'good guys' carry the fire, and the dying father urges his son to always 'carry the fire'. 'On this road there are no godspoke men. They are gone and they have taken with them the world. Query: How does the never to be differ from what never was? ${ }^{24}$ On the road they meet a wandering old man who calls himself Ely (the only named person in the book) who suggests: 'There is no God. No?' 'There is no God and we are his prophets.' 25

We see the world for most of the novel through the largely fatalistic eyes of the father since he knows he is dying but gives all his strength to protecting the boy who becomes the hope for the future when he will 'carry the fire', although his faith in the future seems to die with him.

Increasingly, he rues the lost past and admits when the son ask him questions about the previous world that 'There is no past [...] There is no later. This is later.' 26

The son becomes, according to Cooper, both the grail and the grailbearer as when he brings water to his dying father: 'He took the cup and moved away and when he moved the light moved with him. ${ }^{27}$ By the end, he has become the object that brings the essence of divinity back to a corrupted world, ${ }^{28}$ and an image of the future in which all the avarice and atrocity of which the human race is capable is being expended in a rage now reaching its inevitable conclusion'. ${ }^{29}$

Cooper suggests that the boy becomes a symbol of mercy and forgiveness and a representative of the 'good guys' who do not kill and eat people, but that the book's conclusion is by no means triumphal, with human survival by no means certain. Whilst the world has been 'brutally shorn of referents no longer relevant', redemption may just be available through hope 'passed from man to man through all of time' and longing - itself a form of redemption.

\section{The End of the Road?}

McCarthy is frequently seen as an agnostic writer. However, despite the overwhelming threat of material, cultural and psychological entropy there is evidence that he wanted to suggest a more hopeful ending than his 'godless wasteland', 'cauterised terrain' or the 'ashen scabland' (so redolent of TS Eliot's 'The Wasteland') might seem to presage.

Jay Ellis argues for this view and sees McCarthy's ending as suggesting a small hope against the 'dimming away of the world'. 30 
I would certainly argue that McCarthy's final epigraph is an expression of hope for the future:

Once there were brook trout in the streams in the mountains. You could see them standing in the amber current where the white edges of their fins wimpled softly in the flow. They smelled of moss in your hand. Polished and muscular and torsional. On their backs were vermiculate patterns that were maps of the world in its becoming. Maps and mazes. Of a thing which could not be put back. Not be made right again. In the deep glens where they lived all things were older than man and they hummed of mystery. ${ }^{31}$

This optimism is strengthened by the enigmatic McCarthy suggesting later, in the Oprah Winfrey interview, when asked what readers should get from the book: 'It would be just to care about things and people and be appreciative. Life is pretty damn good even when it looks bad and we should be appreciative more. We should be grateful. ${ }^{32}$

\section{Birkbeck, University of London}

\section{Notes}

I recommend a book written by an earth scientist- Professor Michael Benton from Bristol University. His 2003 book, When Life Nearly Died: The Greatest Mass Extinction of all Time, covers the cataclysms of the end-Permian period 250 million years ago and the end-Cretaceous period 65 million years ago. It is now thought that these 'mass extinctions' were caused by the earth being hit by enormous meteors or by immense volcanic upheavals. We also now estimate that these events wiped out, respectively, $90 \%$ and $50 \%$ of all known life at the time. In the context of geological time, homo sapiens is a very recent entry, indeed- we have probably existed for approximately $0.00043 \%$ of the time since the Earth was created from the dust of the Universe! Jim Welsh, 'The Filmed McCarthy Novels so far', The Cormac McCarthy Journal, 2011, 87-89 (p. 88). This is echoed in the second novel of the Border Trilogy, The Crossing: 'Along the face of the stone bluffs were old pictographs of man and animals and suns and moons as well as other representations that seemed to have no referent in the world although they once may have.' (p. 135). Cormac McCarthy, The Orchard Keeper (New York: Random House, 1965), p. 258. The Road as text is described by Cant as comprising a continuous sequence of discrete paragraphs with very sparse writing, no chapters and little punctuation. The movement of the text is sympathetic with the hard, monotonous torture of the father and son rich in nouns but largely devoid of verbs. John Cant, Cormac McCarthy, and the Myth of American Exceptionalism (New York: Routledge, 2008), p. 268. Lydia R. Cooper, 'Cormac McCarthy's The Road as Apocalyptic Grail Narrative', Studies in the Novel, 43.2 (2011), 218-236 (p. 221).

Cooper, pp. 218-236 (p. 225).

Welsh, pp. 87-89 (p. 87).

Janet Maslin, 'The Road through Hell, Paved with Desperation', The New York Times, 25 September 2006 < http://nytimes.com/2006/09/25/books/25masl.html > [accessed 1 May 2014]. McCarthy, Cormac, The Road (New York: Alfred A. Knopf, 2006), p. 3. Kindle edition (2013).

McCarthy, The Road, p. 89.

McCarthy, The Road, p. 57.

McCarthy, The Road, p. 55.

Father and son are cast by McCarthy as 'pilgrims in a fable' (The Road, p. 3), and Cant agrees with others that the switch from an oedipal theme in his earlier works to a 
father/son relationship in The Road was triggered by his very close relationship with his second son John whom he fathered relatively late in a personal life orchestrated by three failed marriages. This is borne out by the Oprah Winfrey interview: 'I just had this image of these fires up on the hill and everything being laid to waste and I thought a lot about my little boy'.

Thomas A. Carlson, 'With the World at Heart: reading Cormac McCarthy's The Road with Augustine and Heidegger', Religion and Literature, 39.3 (2007), 47-58 (p. 57) < http://www.jstor.org/stable/40060084> [accessed 1 May 2014]. Mark Foster, 'The Lonely Road', Film Quarterly, 63.3 (2010), 14-17 < http://www.filmquarterly.org/2010/03/the-lonely-road/> [accessed 1 May 2014]. Carlson, pp. 47-58.

Carlson, pp. 47-58 (p. 54).

McCarthy, The Road, p. 12.

McCarthy, The Road, p. 187.

Cooper, pp. 218-236 (p. 225).

In January 2014, I spent some time researching the Cormac McCarthy Papers, in the fine Wittliff Collections at the Altek Library of Texas State University, San Marcos. In an early draft, the novel's title was 'The Grail'. [See Box 91.86-91].

$24 \quad$ McCarthy, The Road, p. 32.

$25 \quad$ McCarthy, The Road, p. 169.

$26 \quad$ McCarthy, The Road, p. 54.

$27 \quad$ McCarthy, The Road, p. 277.

28 For example, the woman who adopts the orphaned boy at the end seems to have a reverence towards her new child: 'breath of God was in his breath yet though it pass from man to man through time' (The Road, p. 286).

McCarthy, The Road, p. 225.

Jay Ellis, 'Another Sense of Ending: The Keynote Address to the Knoxville Conference', The Cormac McCarthy Journal, Special Issue: The Road, 6 (2008), 22-38 (p. 37) <http://www.jstor.org/stable/42909379> [accessed 1 May 2014].

$31 \quad$ McCarthy, The Road, p. 287.

32 'Interview with Oprah Winfrey', Oprah Winfrey Show, CBS Television, 5 June 2007 <http://www.oprah.com/oprahsbookclub/Oprahs-Exclusive-Interview-with-CormacMcCarthy-Video $>$ [accessed 1 May 2014].

\section{Works Cited}

Benton, Michael, When Life Nearly Died: The Greatest Mass extinction of all Time (London: Thomas and Hudson, 2003)

Boguta-Marchez, Hanna, The Evil, the Fated, the Biblical: The Latent Metaphysics of Cormac McCarthy (Newcastle, UK: Cambridge Scholars Printing, 2012)

Cant, John, Cormac McCarthy, and the Myth of American Exceptionalism (New York: Routledge, 2008)

Carlson, Thomas A., 'With the World at Heart: reading Cormac McCarthy's The Road with Augustine and Heidegger', Religion and Literature, 39.3 (2007), 47-58 < http://www.jstor.org/stable/40060084 > [accessed 1 May 2014]

Cooper, Lydia R, 'Cormac McCarthy's The Road as Apocalyptic Grail Narrative', Studies in the Novel, 43.2 (2011), 218-236

Crownshaw, Richard, 'Deterritorializing the "Homeland" in American Studies and American Fiction after 9/11', Journal of American Studies, 757-776 <doi:10.1017/S0021875811000946> [accessed 1 May 2014]

Ellis, Jay, 'Another Sense of Ending: The Keynote Address to the Knoxville Conference', The Cormac McCarthy Journal, Special Issue: The Road, 6 
(2008), 22-38 < http://www.jstor.org/stable/42909379> [accessed 1 May 2014].

Foster, Mark, 'The Lonely Road', Film Quarterly, 63.3 (2010), 14-17

< http://www.filmquarterly.org/2010/03/the-lonely-road/> [accessed 1 May 2014]

Frye, Steven, ed., The Cambridge Companion to Cormac McCarthy (Cambridge: Cambridge University Press, 2013)

Hardwig, Bill, 'Cormac McCarthy's The Road and a world to come', Studies in American Naturalism, 8.1 (2013), 38-51

Josephs, Allen, 'The Quest for God in The Road', in The Cambridge Companion to Cormac McCarthy, ed. by Steven Frye (Cambridge: Cambridge University Press, 2013), pp. 133-145

Maslin, Janet, 'The Road through Hell, Paved with Desperation', The New York Times, 25 September 2006 <http://nytimes.com/2006/09/25/books/25masl.html > [accessed 1 May 2014]

McCarthy, Cormac, The Orchard Keeper (New York: Random House, 1965) The Crossing (New York: Alfred A. Knopf, 1994) No Country for Old Men (New York: Alfred A. Knopf, 2005) The Road (New York: Alfred A. Knopf, 2006), Kindle edition (2013)

Welsh, Jim, 'The Filmed McCarthy Novels, So Far', The Cormac McCarthy Journal, 9.1 (2011), 87-89 <http://www.jstor.org/stable/42909427>

Woodward, Richard B., 'Cormac McCarthy's Venomous Fiction', The New York Times, 19 April 1992 <http://www.nytimes.com/books/98/05/17/specials/mccarthyvenom.html>

Winfrey, Oprah, 'Interview with Oprah Winfrey', CBS Television, 5 June 2007 $<$ http://www.oprah.com/oprahsbookclub/Oprahs-Exclusive-Interviewwith-Cormac-McCarthy-Video>

\section{Filmography}

The Road, dir. by John Hillcoat, with Cormac McCarthy and Joe Penhall (Dimension Films, 2009) 